NOTE

\title{
Cancer pagurus bacilliform virus (CpBV) infecting juvenile European edible crabs $C$. pagurus from UK waters
}

\author{
K. S. Bateman*, G. D. Stentiford \\ Centre for Environment, Fisheries and Aquaculture Science (Cefas), Barrack Road, Weymouth, Dorset DT4 8UB, UK
}

\begin{abstract}
This study provides the first description of an intranuclear bacilliform virus infecting the hepatopancreatic epithelial cells of juvenile European edible crab Cancer pagurus from the English Channel, UK. This is the first field report of a virus infecting a member of the Cancer genus and follows a report of a different virus infection detected in C. pagurus held under experimental conditions. We have named the virus Cancer pagurus bacilliform virus ( $\mathrm{CpBV}$ ). The morphology and size of the nucleocapsid and the complete virion align the virus most closely with intranuclear bacilliform viruses reported from other decapod species. The virus was only observed in juvenile C. pagurus with carapace widths ranging between 20 and $70 \mathrm{~mm}$. Viral infection was not observed in crabs above the minimum landing size of $140 \mathrm{~mm}$ carapace width. Due to the importance of $C$. pagurus as a fisheries target, the increasing relative reliance on crustacean fisheries in Europe and the relative dearth of information on diseases of this species, it is pertinent to consider the effects that infections such as $C p B V$ may have on mortality of juvenile crabs and on the sustainability of the fishery as a whole.
\end{abstract}

KEY WORDS: Cancer pagurus $\cdot$ Bacilliform virus $\cdot$ TEM $\cdot$ Histology $\cdot$ Intranuclear $\cdot$ Hepatopancreas · Epithelial cells Resale or republication not permitted without written consent of the publisher

\section{INTRODUCTION}

Viruses are the most abundant members of marine ecosystems and can be found infecting all types of marine organisms, from protists to molluscs and crustaceans to fish and mammals (Munn 2006). Despite their ubiquity, there are surprisingly few reports on their presence in wild marine animals. In this respect, crustaceans are no exception, with only limited examples of viral disease in species obtained from the wild (Johnson 1984, Shields \& Behringer 2004, Stentiford et al. 2004).

Crustacean fisheries are key marine resources in Europe. In many countries (such as the UK) crustaceans are amongst the most valuable targets in marine fisheries, ranking above several finfish species in terms of production quantity and value. The European edible crab Cancer pagurus supports a large fishery in the UK, with 14500 t landed during 2005, with a first sale value of approximately $€ 31.5$ million. UK landings contributed $43 \%$ of the total European catch for this species (www.fao.org/ fishery/statistics/ global-production/1).

Several protistan pathogens have been described from English Channel stocks of Cancer pagurus (Stentiford et al. 2002, 2003, 2007). However, to date, only one virus, C. pagurus systemic bunya-like virus ( $C p \mathrm{SBV})$, has been described from the Cancer genus (Corbel et al. 2003). This virus was discovered in control crabs during white spot syndrome virus (WSSV) challenge trials with $C$. pagurus. Hemolymph from $C p S B V-$ infected crabs contained numerous virions measuring 60 to $70 \mathrm{~nm}$ virions. Virions were also present within the cytoplasm, between cells and within cytoplasmic vesicles of a number of cell types in the gill, hepatopancreas, heart and connective tissues. However, the presence, prevalence and distribution of $\mathrm{CpSBV}$ in wild populations are currently unknown (Corbel et al. 2003). 
Lack of reports of viral infections in Cancer crabs may demonstrate reduced susceptibility or may be an artefact of sampling bias, with a focus on larger, mature crabs that may be less susceptible to infection (Johnson 1984). Size and age variations affect the pathogenicity of many infections; Pestal et al. (2003) showed that bitter crab disease (BCD) was more prevalent in juvenile snow crabs Chionoecetes opilio and may be related to frequency of moulting, as adults cease moulting and are therefore less susceptible to infection.

Edible crabs were sampled as part of a research contract studying population level effects of disease. Crabs of varying size were assessed for disease using histology and electron microscopy. Here we provide the first description of a virus, Cancer pagurus bacilloform virus $(C p \mathrm{BV})$, in wild crabs of the Cancer genus. $C p \mathrm{BV}$ is morphologically similar to other intranuclear bacilliform viruses (IBVs) described from crabs, freshwater crayfish and from penaeid shrimps (Johnson \& Lightner 1988, Huger \& Krieg 1991, Stentiford et al. 2004).

\section{MATERIALS AND METHODS}

European edible crabs Cancer pagurus were sampled from the fishery in the South Kimmeridge Bay region of Dorset, UK (Fig. 1). Dispensation licences from the United Kingdom Marine Fisheries Agency (Council Regulation 850/98) allowed for the sampling of legally undersized (carapace width $[\mathrm{CW}]<140 \mathrm{~mm}$ ) and legal sized (CW $>140 \mathrm{~mm}$ ) crabs, both from the fishery off South Kimmeridge Bay and from the shoreline directly inshore from the fishery site.

Cancer pagurus were captured in 2 sets of baited creels from the South Kimmeridge Bay region in April 2007. The first string of pots was laid between $50^{\circ} 32.50^{\prime} \mathrm{N}, 002^{\circ} 10.00^{\prime} \mathrm{W}$ and $50^{\circ} 32.00^{\prime} \mathrm{N}$, $002^{\circ} 10.00^{\prime} \mathrm{W}_{;}$the second string of pots was laid between $50^{\circ} 32.50^{\prime} \mathrm{N}$, $002^{\circ} 11.00^{\prime} \mathrm{W}$ and $50^{\circ} 32.00^{\prime} \mathrm{N}, 002^{\circ} 11.00^{\prime} \mathrm{W}$. Similarly, juvenile C. pagurus $(\mathrm{CW}$ $<75 \mathrm{~mm}$ ) were collected from the shoreline, directly inshore from the fishery site $\left(50^{\circ} 36.28^{\prime} \mathrm{N}, 002^{\circ} 08.30^{\prime} \mathrm{W}\right)$. Following transportation to the Centre for Environment, Fisheries and Aquaculture Science (Cefas) laboratory, crabs were assessed for external signs of damage and shell disease and processed for histology and electron microscopy.

We sampled 150 Cancer pagurus (60 with $\mathrm{CW}<100 \mathrm{~mm}, 50$ with $\mathrm{CW}$ between
100 and $140 \mathrm{~mm}$, and 40 with $\mathrm{CW}>140 \mathrm{~mm}$ ). Crabs were anaesthetised by chilling on ice for $30 \mathrm{~min}$ before dissection. Hepatopancreas, gill, gonad, heart and body muscle was excised and placed immediately into Davidson's seawater fixative for $24 \mathrm{~h}$, then transferred to $70 \%$ industrial methylated spirit. Samples were infiltrated with paraffin under vacuum using standard protocols. Sections were cut at a thickness of 3 to $5 \mu \mathrm{m}$, mounted onto glass slides, and stained with haematoxylin and eosin (H\&E) or Feulgen. Stained sections were analysed by light microscopy (Nikon Eclipse E800); digital images and measurements were obtained using the Lucia ${ }^{\mathrm{TM}}$ Screen Measurement System (Nikon).

Small blocks $\left(2 \mathrm{~mm}^{3}\right)$ of hepatopancreas were fixed for electron microscopy in $2.5 \%$ glutaraldehyde in $0.1 \mathrm{M}$ sodium cacodylate buffer ( $\mathrm{pH} 7.4$ ) for $2 \mathrm{~h}$ at room temperature. Fixed tissue samples were rinsed in $0.1 \mathrm{M}$ sodium cacodylate buffer ( $\mathrm{pH} 7.4$ ) and post-fixed for $1 \mathrm{~h}$ in $1 \%$ osmium tetroxide in $0.1 \mathrm{M}$ sodium cacodylate buffer. Specimens were washed in 3 changes of $0.1 \mathrm{M}$ sodium cacodylate buffer before dehydration through a graded acetone series. Specimens were embedded in Agar 100 epoxy resin (Agar Scientific, Agar 100 pre-mix kit medium) and polymerised overnight at $60^{\circ} \mathrm{C}$ in an oven. Semi-thin (1 to $2 \mu \mathrm{m}$ ) sections were stained with Toluidine Blue for viewing with a light microscope to identify suitable target areas. Ultrathin sections ( 70 to $90 \mathrm{~nm}$ ) of target areas were mounted on uncoated copper grids and stained with $2 \%$ aqueous uranyl acetate and Reynolds' lead citrate (Reynolds 1963). We examined grids using a JEOL JEM 1210

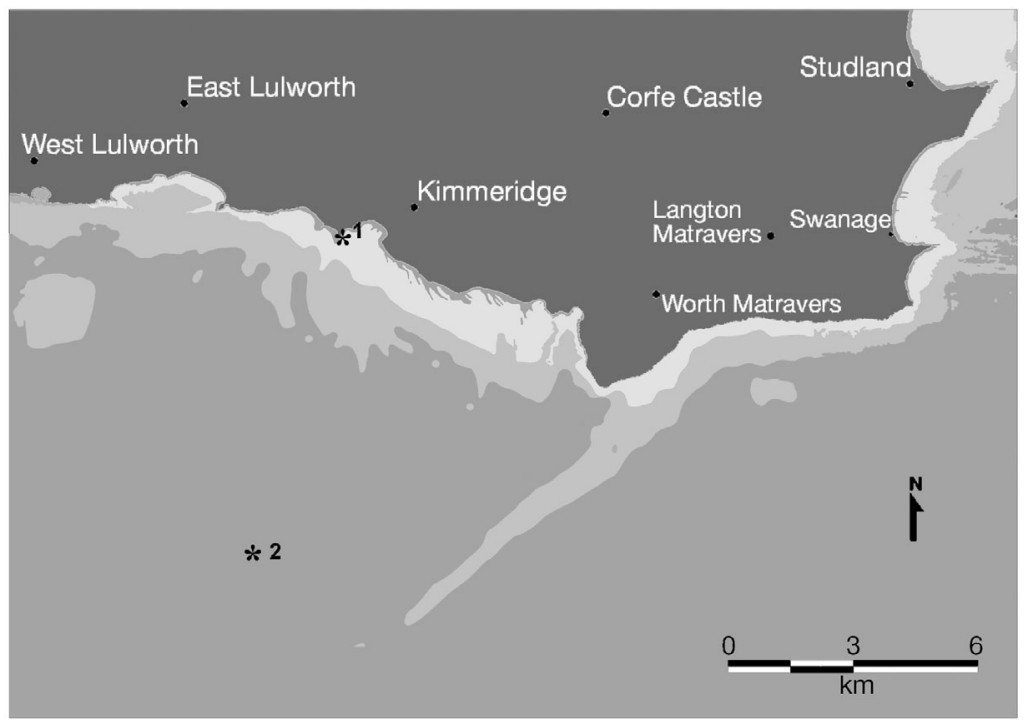

Fig. 1. South coast of the UK. Juvenile Cancer pagurus were collected from the South Kimmeridge Bay shoreline (1), directly inshore from the fishery site (2), where C. pagurus were captured using baited creels 

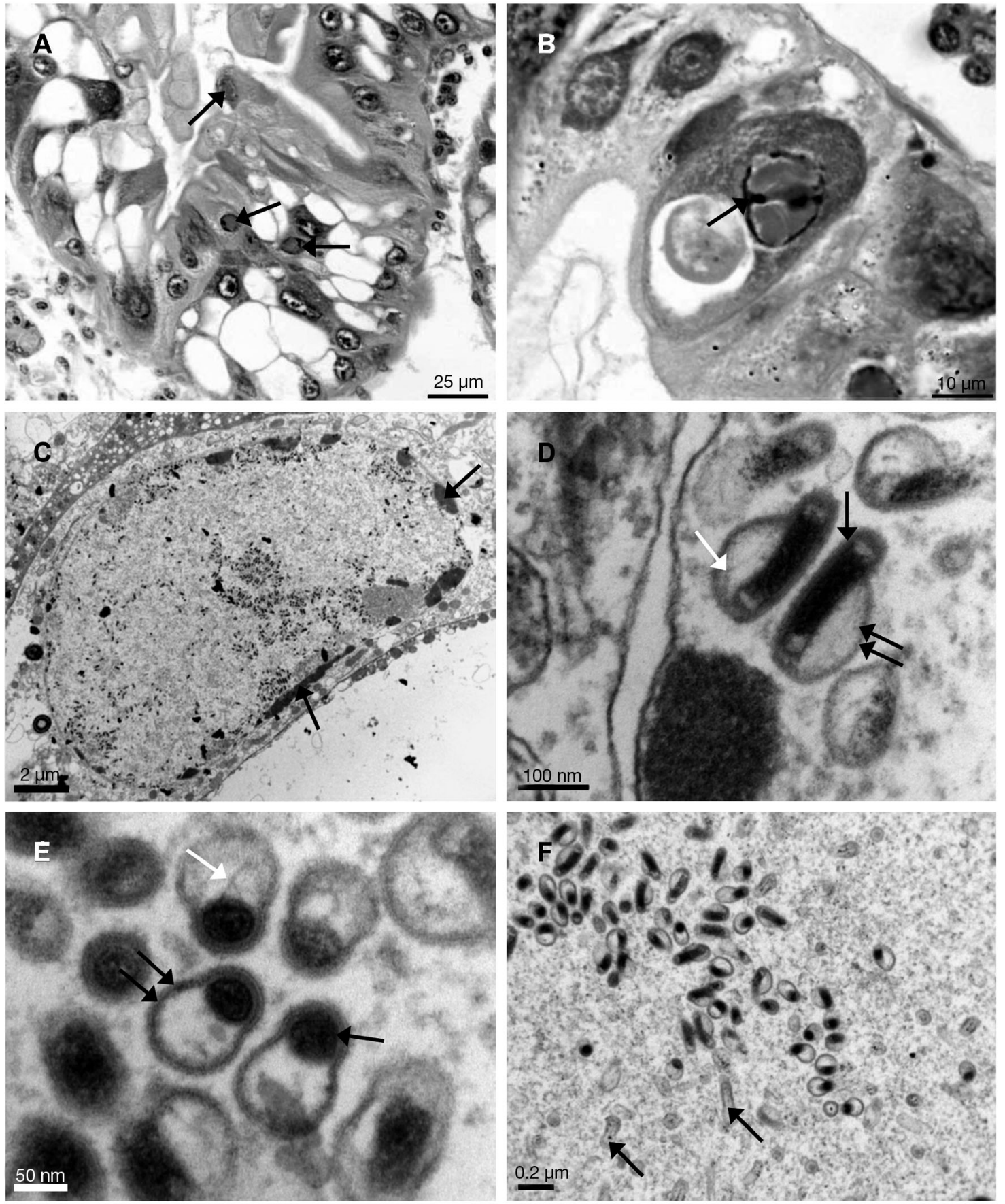

Fig. 2. Cancer pagurus infected with C. pagurus bacilliform virus (CpBV). (A) Hepatopancreas of $C p B$-infected C. pagurus, reserve $(\mathrm{R})$ and fibrillar $(\mathrm{F})$ cells contain enlarged nuclei with marginal chromatin pattern and fine granular eosinophilic matrix (arrows). H\&E stain. Scale bar $=25 \mu \mathrm{m}$. (B) F-cell within hepatopancreas tubule with enlarged nucleus with marginalized chromatin. Margination of the chromatin has formed septa (arrow) that has led to intra-nuclear compartmentalisation. A putative subnucleic lysosome is also present. H\&E. Scale bar $=10 \mu \mathrm{m}$. (C) Enlarged nucleus from epithelial cell of hepatopancreatic tubule displaying marginalised chromatin (arrow) and containing rod-shaped bacilliform virions. Virions are present in transverse and longitudinal section. TEM. Scale bar $=2 \mu \mathrm{m}$. (D) Longitudinal section through bacilliform virus. Virions consist of a nucleocapsid (black arrow) surrounded by a trilaminar membrane with a lateral extension (double arrow) at one end. Tail-like appendage can be seen within the expansion (white arrow). TEM. Scale bar $=100 \mathrm{~nm}$. (E) Transverse section through bacilliform virus. Electrondense nucleocapsid (black arrow) is present on one side of the membranous lateral extension (double arrow). Tail-like appendage can be seen within the expansion (white arrow). TEM. Scale bar $=50 \mathrm{~nm}$. (F) Fully formed virions present in transverse and longitudinal section. Free trilaminar envelopes can be seen within the viroplasm (arrows). TEM. Scale bar $=0.2 \mu \mathrm{m}$ 
transmission electron microscope and captured digital images using a Gatan Erlangshen ES500W camera and Gatan Digital Micrograph ${ }^{\mathrm{TM}}$ software.

\section{RESULTS}

A virus infection was found in $5 \%$ of crabs collected from the Kimmeridge Bay fishery and the shoreline. Infections were only recorded in crabs between 20 and $70 \mathrm{~mm} \mathrm{CW}$, with larger individuals and those above the legal CW (140 mm) apparently not infected. Previously described pathogens (Hematodinium spp., Enterospora canceri) and an undescribed Paramarteilia sp. were also discovered infecting crabs from the South Kimmeridge Bay fishery; these results will be presented elsewhere.

Infected crabs showed no obvious external signs of disease. Histological analysis revealed hypertrophied nuclei containing an eosinophilic, finely granular matrix within the epithelial cells of hepatopancreatic tubules (Fig. 2A). Affected nuclei also displayed marginated chromatin with strands of chromatin traversing the nucleoplasm, leading to apparent intranuclear compartmentalisation (Fig. 2B). Affected cells appeared singly or in clusters; cells with hypertrophied nuclei were consistently found to be reserve (R) or fibrillar (F) cells. The infection was not observed in regenerating epithelial (E) or blister (B) cells. Transmission electron microscopy (TEM) revealed rod-shaped virions within enlarged nuclei (Fig. 2C). Virions possessed an elongated electron-dense nucleocapsid with a relatively electron-lucent end. The nucleocapsid was surrounded by a trilaminar envelope, which expanded at one end to form a lateral protuberance (Fig. 2D,E). Within this expansion appeared a fine tail-like structure that emerged from the proximal end of the nucleocapsid (Fig. 2D,E). Virions in various stages of development were observed in the nuclei (Fig. 2F). The mean length of complete virions $(\mathrm{n}=30)$ was $210.9 \pm$ $2.6 \mathrm{~nm}$, with a mean diameter of $60.3 \pm 0.8 \mathrm{~nm}$ and a mean envelope width of $6 \pm 0.2 \mathrm{~nm}$. The mean length of the nucleocapsid was $181.6 \pm 2.5 \mathrm{~nm}$, with a mean diameter of $43.4 \pm 0.4 \mathrm{~nm}$.

\section{DISCUSSION}

We provide the first description of a virus infecting Cancer pagurus sampled directly from the wild. The IBV, $C p B V$, infects the R and F cells of the hepatopancreas of juvenile crabs, with infection apparently absent in crabs above CW $70 \mathrm{~mm}$, including those captured in the fishery (above CW $140 \mathrm{~mm}$ ). Pathology observed in the hepatopancreas is typical of previously described IBV infecting other crustacean species (Johnson 1977, Pappalardo et al. 1986, Johnson \& Lightner 1988, Groff et al. 1993, Edgerton et al. 1996, Stentiford et al. 2004).

Johnson (1984) noted the absence of described virus infections in the commercially significant Cancer genus and speculated that infections may be observed if field surveys included juvenile crabs or those below the legal landing size imposed by the fishery. This study confirms this hypothesis and highlights a need to consider age and size when carrying out disease surveys in wild crustacean hosts. Several pathogens of commercial and ecological significance have been described in C. pagurus from the English Channel fishery, including Hematodinium spp. (Stentiford et al. 2002), Enterospora canceri (Stentiford et al. 2007) and a Paramarteilia sp. (G. D. Stentiford unpubl. data). While the discovery of $C p B V$ in exclusively juvenile C. pagurus from the same fishery may indicate an additional age-specific (and potentially 'silent') mortality driver, further work is required to assess the relative pathogenicity of the virus and its prevalence in juveniles throughout the season and across the geographic range of $C$. pagurus.

Acknowledgements. This work was supported by the UK Department of Environment, Food and Rural Affairs (DEFRA) under contract number F1168.

\section{LITERATURE CITED}

Corbel V, Coste F, Bonami JR (2003) CpSBV, a systemic virus of the edible crab, Cancer pagurus (L.). J Fish Dis 26: $121-126$

Edgerton B, Paasonen P, Henttonen P, Owens L (1996) Description of a bacilliform virus from the freshwater crayfish, Astacus astacus. J Invertebr Pathol 68:187-190

Groff JM, McDowell T, Friedman CS, Hedrick RP (1993) Detection of a nonoccluded baculovirus in the freshwater crayfish Cherax quadricarinatus in North America. J Aquat Anim Health 5:275-279

Huger AM, Krieg A (1991) Baculoviridae: non-occluded baculoviruses, Chap 9. In: Adams JR, Bonami JR (eds) Atlas of invertebrate viruses. CRC Press, Boca Raton, FL, p 287-319

Johnson PT (1977) A viral disease of the blue crab, Callinectes sapidus; histopathology and differential diagnosis. J Invertebr Pathol 29:201-209

Johnson PT (1984) Viral diseases of marine invertebrates. Helgol Meersunters 37:65-98

Johnson PT, Lightner DV (1988) Rod-shaped nuclear viruses of crustaceans: gut-infecting species. Dis Aquat Org 5: $123-141$

Munn CB (2006) Viruses as pathogens of marine organisms from bacteria to whales. J Mar Biol Assoc UK 86:453-467

Pappalardo R, Mari J, Bonami JR (1986) $\tau$ (tau) virus infection of Carcinus mediterraneus; histology, cytopathology and experimental transmission of the disease. J Invertebr Pathol 47:361-368 
Pestal GP, Taylor DM, Hoenig JM, Shields JD, Pickavance R (2003) Monitoring the prevalence of the parasitic dinoflagellate Hematodinium sp. in snow crabs Chionoecetes opilio from Conception Bay, Newfoundland. Dis Aquat Org 53:67-75

Reynolds ES (1963) The use of lead citrate at high $\mathrm{pH}$ as an electron-opaque stain in electron microscopy. J Cell Biol 17:208-212

Shields JD, Behringer DC Jr (2004) A new pathogenic virus in the Caribbean spiny lobster Panulirus argus from the Florida Keys. Dis Aquat Org 59:109-118

Stentiford GD, Green M, Bateman KS, Small HJ, Neil DM, Feist SW (2002) Infection by a Hematodinium-like parasitic dinoflagellate causes pink crab disease (PCD) in the edible

Editorial responsibility: Ken Hasson,

College Station, Texas, USA crab Cancer pagurus. J Invertebr Pathol 79:179-191

Stentiford GD, Evans M, Bateman K, Feist SW (2003) Coinfection by a yeast-like organism in Hematodiniuminfected European edible crabs Cancer pagurus and velvet swimming crabs Necora puber from the English Channel. Dis Aquat Org 54:195-202

Stentiford GD, Bateman K, Feist SW (2004) Pathology and ultrastructure of an intranuclear bacilliform virus (IBV) infecting brown shrimp Crangon crangon (Decapoda: Crangonidae). Dis Aquat Org 58:89-97

Stentiford GD, Bateman KS, Longshaw M, Feist SW (2007) Enterospora canceri n. gen., n. sp., intranuclear within the hepatopancreatocytes of the European edible crab Cancer pagurus. Dis Aquat Org 75:61-72

Submitted: November 8, 2007; Accepted: January 23, 2008 Proofs received from author(s): March 17, 2008 